\title{
Caloranaerobacter azorensis gen. nov., sp. nov., an anaerobic thermophilic bacterium isolated from a deep-sea hydrothermal vent
}

Laboratoire de

Caractérisation des Microorganismes Marins,

Département de

Valorisation des Produits, IFREMER, Centre de Brest, BP 70, 29280 Plouzané, France

\author{
Nathalie Wery, $†$ Jean-Marc Moricet, Valérie Cueff, Joëlle Jean, \\ Patricia Pignet, Françoise Lesongeur, Marie-Anne Cambon-Bonavita \\ and Georges Barbier
}

Author for correspondence: Georges Barbier. Tel: +332982245 21. Fax: +33298224757. e-mail: Georges.Barbier@ifremer.fr
Keywords: bacteria, Caloranaerobacter, Caloranaerobacter azorensis, deep-sea vent, thermophile

\section{INTRODUCTION}

Thermophilic micro-organisms have been isolated from various environments, especially for biotechnological interests, as a source of more thermostable biocatalysts (Kristjansson, 1992). These environments include oil reservoirs, deep aquifers, continental hot springs, shallow marine hydrothermal systems and deep-sea vents. Within the domain Bacteria, various thermophilic and hyperthermophilic marine species have been isolated and described. These bacteria are aerobic heterotrophs (Thermus thermophilus, Rhodothermus marinus, Thermaerobacter marianensis), microaerophilic autotrophs (Aquifex pyrophilus), anaerobic autotrophs (Desulfurobacterium thermolitho-

\footnotetext{
† Present address: Centre for Extremophile Research, Department of Biology and Biochemistry, University of Bath, Bath BA2 7AY, UK.

The EMBL accession number for the 16S rRNA gene sequence of strain MV1087' is AJ272422.
}

trophum) and anaerobic heterotrophs (Thermotogales) (Alfredsson et al., 1988; Manaia \& Da Costa, 1991; Huber et al., 1992; Antoine et al., 1997; Takai et al., 1999). Both aerobic and anaerobic thermophilic heterotrophic bacterial strains have been isolated from deep-sea hydrothermal vents. The aerobic strains have been assigned to the genera Thermus and Bacillus (Marteinsson et al., 1995, 1996) and the anaerobic strains to the genera Thermosipho and Thermotoga within the order Thermotogales, a deep branch of the small-subunit rRNA universal phylogenetic tree (Antoine et al., 1997; Marteinsson et al., 1997; Takai \& Horikoshi, 2000). Finally, an anaerobic strain isolated from deep-sea hydrothermal vents of the MidAtlantic Ridge was recently assigned to a new species of a new genus of the order Thermotogales, Marinitoga camini (Wery et al., 2001).

Collins et al. (1994) used 16S rDNA phylogenetic analysis to define 19 clusters within the genus Clostridium and they subsequently proposed five new 
genera: Caloramator, Filifactor, Moorella, Oxobacter and Oxalophagus (Collins et al., 1994). Evidence for the placement of further genera within the Clostridium subphylum of the Gram-positive bacteria was then presented, leading to the proposal of Johnsonella, Catonella (Willems \& Collins, 1995), Tissierella (Farrow et al., 1995), Fusibacter (Ravot et al., 1999) and Thermohalobacter (Cayol et al., 2000). Members of some of these genera, such as Fusibacter, Thermohalobacter, Caloramator and Moorella, are anaerobic thermophiles. Anaerobic heterotrophic thermophiles of the order Clostridiales have already been isolated from continental hot springs and shallow hydrothermal vents; for example, Moorella glycerini, Caldicellulosiruptor kristjanssonii, Thermoanaerobacter siderophilus and Thermoterrabacterium ferrireducens (Slobodkin et al., 1997a, b, 1999; Bredholt et al., 1999). However, to date, no thermophilic anaerobic heterotrophic species of the order Clostridiales has been isolated and described from deep-sea hydrothermal vents.

In September 1997, samples were collected from deepsea vent fields of the Azores Triple Junction, on the Mid-Atlantic Ridge. In this paper, we report the first characterization of a thermophilic anaerobic bacterium isolated from deep-sea hydrothermal vents and affiliated to the subphylum Clostridium.

\section{METHODS}

Collection of samples. Samples were collected by the manoperated submersible Nautile during the MARVEL cruise, on deep-sea vent fields of the Mid-Atlantic Ridge: Lucky Strike $\left(32^{\circ} 16^{\prime} \mathrm{W}, 37^{\circ} 17^{\prime} \mathrm{N} ;-1600\right.$ to $\left.-1700 \mathrm{~m}\right)$ and Menez-Gwen $\left(31^{\circ} 31^{\prime} \mathrm{W}, 37^{\circ} 51^{\prime} \mathrm{N}\right.$; -800 to $\left.-1000 \mathrm{~m}\right)$. Samples of chimney walls, rock debris and mussels were collected using an insulated box filled with sterilized sea water. They were prepared in an anaerobic chamber and stored at $4{ }^{\circ} \mathrm{C}$ in serum vials filled with sterile seawater under anaerobic conditions $\left(\mathrm{N}_{2}\right.$ headspace gas and $0.5 \mathrm{~g}$ sodium sulfide $1^{-1}$ ).

Growth conditions. The medium YPXS used during the enrichment and the isolation contained $\left(1^{-1}\right): 0.5 \mathrm{~g}$ yeast extract (Difco), $1 \mathrm{~g}$ peptone (Difco), $5 \mathrm{~g}$ oat spelt xylan (Sigma), $10 \mathrm{~g}$ sulfur (Prolabo), $30 \mathrm{~g}$ sea salt (Sigma), 6.05 g PIPES buffer (Sigma) and $1 \mathrm{mg}$ resazurin (Sigma). YTG medium contained $\left(1^{-1}\right): 1 \mathrm{~g}$ yeast extract, $1 \mathrm{~g}$ tryptone, $2 \cdot 5 \mathrm{~g}$ glucose (Sigma), $30 \mathrm{~g}$ sea salt, 6.05 g PIPES buffer and $1 \mathrm{mg}$ resazurin. Glucose was omitted in YT medium. The $\mathrm{pH}$ was adjusted to $7 \cdot 5$ in YPXS medium and to 7 in the other media. The media containing sulfur were sterilized at $100{ }^{\circ} \mathrm{C}$ for $30 \mathrm{~min}$ on two successive days. When sulfur was omitted, sterilization was achieved after $20 \mathrm{~min}$ at $121^{\circ} \mathrm{C}$. Sterile media were transferred into 0 an anaerobic chamber containing $\mathrm{N}_{2} / \mathrm{H}_{2} / \mathrm{CO}_{2}(90: 5: 5)$, reduced by adding sodium sulfide to a final concentration of $0.5 \mathrm{~g} \mathrm{l}^{-1}$ and then distributed into Hungate tubes $(6 \mathrm{ml}$ in a total volume of $16 \mathrm{ml})$ or in serum vials with butyl rubber stoppers $(20 \mathrm{ml}$ in a total volume of $60 \mathrm{ml}$ ). Unless indicated otherwise, cultures were incubated at atmospheric pressure under the anaerobic chamber gas mixture at $65^{\circ} \mathrm{C}$.

Enrichment and isolation procedures. Enrichment culture was performed in YPXS medium, inoculated with $1 \mathrm{ml}$ of the sheltered sample of hydrothermal chimney and incubated at $65^{\circ} \mathrm{C}$, at atmospheric pressure under the anaerobic chamber gas mixture. Cultures were purified by streaking enrichment samples onto YPXS medium solidified with Gelrite (Scott Laboratories) as gelling agent and incubated in jars as reported by Godfroy et al. (1997).

Storage. Cultures in exponential growth phase were stored at $4{ }^{\circ} \mathrm{C}$ or room temperature. For long-term storage, cultures in exponential growth phase were stored anaerobically in cryotubes at -20 and $-80{ }^{\circ} \mathrm{C}$ after the addition of $5 \%$ (v/v) DMSO (Sigma).

Observation of the culture and determination of cell number. Enumeration of cells was performed by direct cell counting using a Thoma chamber (depth $0.02 \mathrm{~mm}$ ). Alternatively, cells were stained with $4^{\prime}, 6^{\prime}$-diamidino-2-phenylindole (DAPI), which was added to the samples at a final concentration of $1 \mathrm{mg} \mathrm{l}^{-1}$. Cells were observed with an Olympus model BH-2 microscope. The turbidity of the cells in YTG medium was also quantified with a spectrophotometer (Spectronic 301; Milton Roy), measuring the optical density at $600 \mathrm{~nm}$. A linear correlation was found between the number of cells per $\mathrm{ml}(C)$ and $\mathrm{OD}_{600}$ from $0 \cdot 1$ to $0 \cdot 25: C=1.25 \times 10^{9} \times \mathrm{OD}_{600}\left(r^{2}=0 \cdot 87\right)$.

Morphology. Gram staining was done using the Bacto 3-step Gram stain Set-S (Difco). For transmission electron microscopy, cells were harvested at the end of exponential phase. The pellet was resuspended and fixed for $1 \mathrm{~h}$ at room temperature in cacodylate buffer $[0 \cdot 4 \mathrm{M}$ sodium cacodylate, $\mathrm{pH} 7 \cdot 4 / 5 \cdot 5 \%$ (w/v) NaCl/8\% (v/v) glutaraldehyde (2:1:1)] and then post-fixed for $1 \mathrm{~h}$ at $4{ }^{\circ} \mathrm{C}$ in another cacodylate buffer $[0.4 \mathrm{M}$ sodium cacodylate, $\mathrm{pH} 7 \cdot 4 / 10 \%$ (w/v) $\left.\mathrm{NaCl} / 2 \%(\mathrm{w} / \mathrm{v}) \mathrm{OsO}_{4}(1: 1: 2)\right]$. Following dehydration by immersion in different solutions with increasing ethanol concentrations, cells were embedded in Spurr's resin, thin sectioned, contrasted with $1 \%(\mathrm{w} / \mathrm{v})$ uranyl acetate and $1 \%$ $(\mathrm{w} / \mathrm{v})$ lead citrate (Bio-Rad) and examined in a 100CXII transmission electron microscope (JEOL).

Tests for sporulation. The presence of spores was determined by phase-contrast microscope observation of cultures stained with malachite solution at different phases of growth. The presence of heat-resistant spores was tested by heating cultures obtained previously on YTG and YT media. On each medium, different cultures were heated at 80, 90 and $100{ }^{\circ} \mathrm{C}$ for 10,20 and $60 \mathrm{~min}$. Samples of the cultures were then observed. The heat resistance of cells was also tested as reported by Cayol et al. (2000).

Analyses of amino acids, organic acids and aromatic acids. Each sample was centrifuged for $30 \mathrm{~min}$ at $8000 \mathrm{~g}$ to eliminate cells. Half of the supernatant was transferred to an ultrafree-CL-PLGC 10000 NMWL unit (Millipore) and centrifuged at $4500 \mathrm{~g}$ for several hours. The filtrate $(20 \mu \mathrm{l})$ was mixed with $30 \mu \mathrm{l}$ of a solution of ethanol/water/ triethylamine $(2: 2: 1)$ and vacuum-dried. A derivatizing solution $(20 \mu \mathrm{l})$ containing ethanol/water/triethylamine/ phenylisothiocyanate ( $7: 1: 1: 1$ by vol.) was then added. After $10 \mathrm{~min}$ at room temperature, the sample was vacuumdried. Analysis of amino acids by HPLC (Alliance 2690; Waters) was then conducted under the conditions and with the products of the Waters PicoTag method (WAT007360; Waters). In the other part of the supernatant, proteins were precipitated with a solution of 5-sulfosalicylic acid at $2 \%$ (w/v) overnight at $4{ }^{\circ} \mathrm{C}$ and removed by centrifugation at $8000 \mathrm{~g}$ for $10 \mathrm{~min}$. The supernatant was then used for HPLC analyses of glucose, aromatic acids and linear organic acids. For analysis of glucose and linear organic acids, $20 \mu \mathrm{l}$ 
supernatant was eluted on an $\mathrm{H}^{+}$exclusion column (polyspher OAKC 1.51270 ; Merck) at $60{ }^{\circ} \mathrm{C}$ by a $9 \mathrm{mM} \mathrm{H}_{2} \mathrm{SO}_{4}$ solution with a flow rate of $0.35 \mathrm{ml} \mathrm{min}^{-1}$ and detected using a differential refractometer (refractometer 410; Waters). For analysis of aromatic acids, $20 \mu \mathrm{l}$ supernatant was eluted on an $\mathrm{H}^{+}$exclusion column (column 28352; Chrompack) at $65^{\circ} \mathrm{C}$ by a $4.5 \mathrm{mM} \mathrm{H}_{2} \mathrm{SO}_{4}$ solution with a flow rate of $0.5 \mathrm{ml} \mathrm{min}-1$ and detected by absorbance at $210 \mathrm{~nm}$ (UV detector 486; Waters).

Determination of growth parameters. All experiments were conducted in triplicate. Cells were grown in Hungate tubes on YTG medium. Temperatures were maintained with aluminium heating blocks (Bioblock) and monitored with temperature probes placed in control tubes. To determine the effect of $\mathrm{pH}$ on growth, YTG medium was modified by using the following buffers (Sigma), each at a concentration of $20 \mathrm{mM}$ : for $\mathrm{pH} 2,3$ and 4 , no buffer; for $\mathrm{pH} 5,5.5$ and 6 , MES; for $\mathrm{pH} 6.5$ and 7, PIPES; for $\mathrm{pH} 7.5$ and 8, HEPES; for $\mathrm{pH} 8 \cdot 5$ and 9, AMPSO [3-(1,1-dimethyl-2-hydroxyethyl)amino-2-hydroxypropanesulfonic acid]; for $\mathrm{pH} 10$, no buffer. In the anaerobic chamber, sodium sulfide was added and the $\mathrm{pH}$ was measured at room temperature and adjusted, if necessary, with $0 \cdot 1 \mathrm{M} \mathrm{HCl}$ and $0 \cdot 1 \mathrm{M} \mathrm{NaOH}$. To determine the salt requirement, YTG medium was prepared with different dilutions of sea salt. The effect of salinity was determined at $65^{\circ} \mathrm{C}$ and $\mathrm{pH}$ 7. The effect of $\mathrm{pH}$ was determined at $65^{\circ} \mathrm{C}$ and $30 \mathrm{~g}$ sea salt $1^{-1}$. The effect of temperature was determined at $\mathrm{pH} 7$ and $30 \mathrm{~g}$ sea salt $\mathrm{l}^{-1}$. Growth rates $(\mu)$ were obtained after linear regression of the curve $\ln (\mathrm{OD})$ versus time and the doubling time $\left(t_{\mathrm{d}}\right)$ was calculated as $t_{\mathrm{d}}=\ln (2) / \mu$. Confidence intervals and related standard error were calculated as reported by Barbier et al. (1999).

Determination of growth requirements. All experiments were carried out in duplicate. The ability of isolate MV1087 to use gluten, brain/heart infusion, yeast extract, peptone or tryptone was tested at $2 \mathrm{~g} \mathrm{l}^{-1}$ in a medium containing $\left(1^{-1}\right)$ : $30 \mathrm{~g}$ sea salt, $10 \mathrm{ml}$ minal solution (Balch et al., 1979), $10 \mathrm{ml}$ vitamin solution (Balch et al., 1979), $5 \mathrm{ml} 7 \%(\mathrm{w} / \mathrm{v}$ ) $\mathrm{KH}_{2} \mathrm{PO}_{4}$ and $6.05 \mathrm{~g}$ PIPES. A solution of 20 amino acids each at $0 \cdot 1 \mathrm{~g} \mathrm{l}^{-1}$ was also tested. A stock solution containing each amino acid at a concentration of $1 \mathrm{~g} \mathrm{l}^{-1}$ was sterilized separately by filtration. The ability of isolate MV $1087^{\mathrm{T}}$ to use other substrates was tested in a medium containing $\left(1^{-1}\right)$ : $30 \mathrm{~g}$ sea salt, $10 \mathrm{ml}$ mineral solution, $10 \mathrm{ml}$ vitamin solution, $5 \mathrm{ml} 7 \%$ (w/v) $\mathrm{KH}_{2} \mathrm{PO}_{4}, 6.05 \mathrm{~g}$ PIPES, $1 \mathrm{~g}$ yeast extract, $1 \mathrm{~g}$ tryptone and the substrate tested. The substrates tested were: $\mathrm{D}(+)$-sucrose, $\mathrm{D}(+)$-glucose, $\mathrm{D}(+)$-cellobiose, $\mathrm{D}(+)$ xylose, starch, cellulose, dextran, xylan, glycerol, methanol, ethanol, acetate, propionate, pyruvate and lactate. Polysaccharides were tested at $5 \mathrm{~g}^{-1}$, sugars at $2 \cdot 5 \mathrm{~g} \mathrm{l}^{-1}$, alcohols at $5 \mathrm{ml}^{-1}$ and acids at $2 \mathrm{~g} \mathrm{l}^{-1}$. Sugar and vitamin solutions were sterilized by filtration and added just before inoculation. Tests were performed in Hungate tubes. To avoid growth on substrates brought with the inoculum, positive cultures were transferred once ( $10 \%$ inoculum) and the final concentration of the cells was determined by direct counting. Amino, organic and aromatic acids were analysed during culture on YTG medium. The variations in concentration of amino acids and organic acids were controlled in uninoculated media. API50CH strips (bioMérieux) with medium 50CHE (bioMérieux) were used to test the consumption of other carbohydrates and APIZYM strips (bioMérieux) were used to test enzyme activities, following the instructions of the supplier. The strips were incubated at $65^{\circ} \mathrm{C}$, instead of $37^{\circ} \mathrm{C}$.
Effect of possible electron acceptors. The effects on growth of sulfur $\left(10 \mathrm{~g} \mathrm{l}^{-1}\right)$, sodium thiosulfate $(20 \mathrm{mM})$, sodium sulfite $(20 \mathrm{mM}), \mathrm{FeCl}_{3}(5 \mathrm{mM})$, sodium nitrite $(20 \mathrm{mM})$ and sodium nitrate $(20 \mathrm{mM})$ were tested on YTG medium. The experiments were performed in triplicate. The cell concentration was determined by direct cell counting. Production of $\mathrm{H}_{2} \mathrm{~S}$ was examined using lead acetate paper (Whatman).

DNA extraction and purification. Genomic DNA was extracted as reported by Barbier et al. (1999), with incubation at $45^{\circ} \mathrm{C}$ for $0.5 \mathrm{~h}$ instead of for $3 \mathrm{~h}$ at $40{ }^{\circ} \mathrm{C}$. The quality of the extraction was checked on a $0.8 \%(\mathrm{w} / \mathrm{v})$ agarose gel containing $0.8 \mu \mathrm{g}$ ethidium bromide $\mathrm{ml}^{-1}$.

DNA base composition. The DNA was purified by $\mathrm{CsCl}$ gradient centrifugation. After precipitation, the DNA was suspended in TE buffer containing $1.075 \mathrm{~g} \mathrm{CsCl} \mathrm{ml}^{-1}$ and $10 \mathrm{mg}$ ethidium bromide $\mathrm{ml}^{-1}$ and centrifuged for $15 \mathrm{~h}$ at 65000 r.p.m. (Beckman preparative ultracentrifuge, model CO-L70K; rotor 70.1 Ti). The DNA band was removed with a syringe. The ethidium bromide was then extracted by using 2-propanol saturated with $\mathrm{CsCl}$. Finally, the solution was dialysed overnight against 11 TE buffer. The $\mathrm{G}+\mathrm{C}$ content of the DNA was determined by thermal denaturation under the conditions reported by Raguénès et al. (1997). A calibration curve was obtained by using ultrapure DNAs from Escherichia coli strain B $(50 \mathrm{~mol} \% \mathrm{G}+\mathrm{C})$, Clostridium perfringens $(26.5 \mathrm{~mol} \% \mathrm{G}+\mathrm{C})$ and Micrococcus luteus $(72$ $\mathrm{mol} \% \mathrm{G}+\mathrm{C}$ ) as standards (Sigma).

Amplification of the 16S rDNA. The 16S rDNA was selectively amplified from purified genomic DNA by using the bacterial forward primer SAdir (5'-AGAGTTTGATCATGGCTCAGA-3'), corresponding to positions 8-28 of the Escherichia coli 16S rRNA, and the bacterial reverse primer S17rev (5'-GTTACCTTGTTACGACTT-3'), corresponding to the complement of positions 1493-1509. The following reagents were combined in a total volume of $50 \mu 1$ : $100 \mathrm{ng}$ template DNA, $5 \mu 110 \times$ PCR buffer $[100 \mathrm{mM}$ Tris/HCl, pH 9.0, $50 \mathrm{mM} \mathrm{KCl}, 1 \cdot 5 \mathrm{mM} \mathrm{MgCl}, 0 \cdot 1 \%(\mathrm{w} / \mathrm{v})$ Triton X-100, $0 \cdot 2 \mathrm{ml} \mathrm{BSA}$ or gelatin $\mathrm{ml}^{-1}$; Appligene-Oncor], 2.5 U Taq DNA polymerase (Appligene-Oncor), $200 \mu \mathrm{M}$ of each dNTP, $2 \mathrm{mM}$ forward primer and $2 \mathrm{mM}$ reverse primer. The complete reaction mixture was overlaid with mineral oil (Sigma) and incubated in a 96 Gradient thermocycler (Stratagene). The PCR temperature profile used was: $94^{\circ} \mathrm{C}$ for $3 \mathrm{~min}$ followed by 30 cycles of $94^{\circ} \mathrm{C}$ for $1 \mathrm{~min}, 50^{\circ} \mathrm{C}$ for $1.5 \mathrm{~min}$ and $72{ }^{\circ} \mathrm{C}$ for $2 \mathrm{~min}$ and finally an extension step at $72{ }^{\circ} \mathrm{C}$ for $6 \mathrm{~min}$. PCR results were analysed by electrophoresis on $0.8 \%(\mathrm{w} / \mathrm{v})$ agarose TAE gels $(0.04 \mathrm{M}$ Tris/ acetate, $0.001 \mathrm{M}$ EDTA), containing $0.8 \mu \mathrm{g}$ ethidium bromide $\mathrm{ml}^{-1}$. All images were obtained with a Fluor-S multiImager (Bio-Rad).

16S rDNA sequence analysis. The PCR product was sequenced using the primers described by Raguénès et al. (1996). This work was done by Genome Express (France) and 1443 positions of the 16S rDNA sequence were determined. The sequence was then compared with others available in GenBank using BLAST (Altschul et al., 1990). A multiple sequence file was obtained by using the MegAlign program of the DNASTAR package (Promega). Alignments and similarity levels were obtained by the CLUSTAL W method with weighted residues (Thompson et al., 1994). The alignment was then corrected manually using the multiple sequence alignment editor SEAVIEW and the phylogenetic reconstruction was produced using PHYLO_WIN (Galtier et al., 1996) with the following algorithms: Jukes-Cantor 

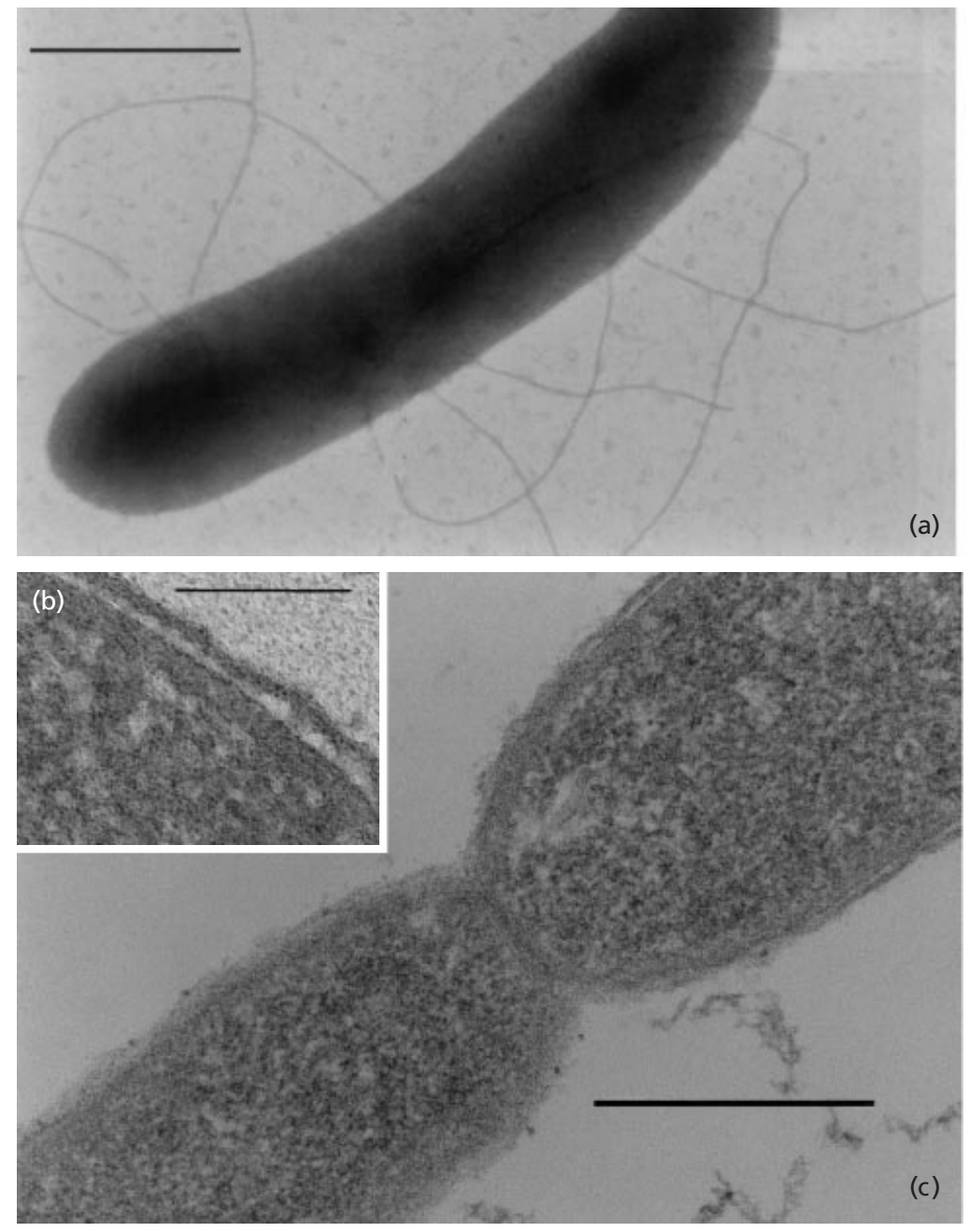

Fig. 1. Transmission electron micrograph of strain $M V 1087^{\top}$ showing (a) cell shape and flagella (negatively stained), (b) Gramnegative type cell wall and (c) pinching mechanism of cell division. Bars, 0.5 (a), 0.1 (b) and 0.4 (c) $\mu \mathrm{m}$. distance matrix and successively the neighbour-joining (Saitou \& Nei, 1987), maximum-parsimony (Lake, 1987) and maximum-likelihood (Felsenstein, 1981) methods. Bootstrap values were determined according to Felsenstein (1985).

\section{RESULTS}

\section{Isolation}

During the MARVEL oceanographic cruise, YPXS medium was inoculated with a sample from the Lucky Strike deep-sea hydrothermal site of the Mid-Atlantic Ridge. The sample was composed of rocks from the bottom of a diffuser supporting mussels, collected at a depth of $1650 \mathrm{~m}$. After a few days at $65^{\circ} \mathrm{C}$ under anaerobic conditions, motile straight rods were observed. The strain was purified by streaking on plates and the isolate was called MV1087 ${ }^{\mathrm{T}}$.

\section{Morphology}

Microscope observations indicated that cells of isolate MV1087 ${ }^{\mathrm{T}}$ were motile, round-ended rods; flagella were observed (Fig. 1a). The cells stained Gram-negative in all phases of growth. Electron microscopy of thin sections of strain $\mathrm{MV} 1087^{\mathrm{T}}$ revealed a cell wall ultrastructure typical of Gram-negative bacteria (Fig. 1b) and cell division with a pinching mechanism (Fig. 1c). The cells appeared singly, in pairs or in short chains (fewer than five cells). Under optimal growth conditions on YTG medium, cells were $0.3-0.5 \mu \mathrm{m}$ wide and $0 \cdot 5-2 \mu \mathrm{m}$ long. Cells more than $20 \mu \mathrm{m}$ long were formed occasionally. Spores were not observed, but cells survived pasteurization at $100^{\circ} \mathrm{C}$ for $20 \mathrm{~min}$. In cultures stored for a few days at $4{ }^{\circ} \mathrm{C}$, in poor media or at high $\mathrm{pH}$, some terminal, round, external bodies were observed. Their significance remains unknown.

\section{Determination of growth parameters}

Growth was observed from 45 to $65^{\circ} \mathrm{C}$ and the optimum temperature for growth was around $65^{\circ} \mathrm{C}$ (Fig. 2a). No growth was observed at 40 or $70^{\circ} \mathrm{C}$. Growth was observed at sea salt concentrations ranging from 10 to $100 \mathrm{~g} \mathrm{l}^{-1}$ (corresponding to $6 \cdot 5-65 \mathrm{~g}$ $\mathrm{NaCl}^{-1}$ ) and the optimum sea salt concentration was around $30 \mathrm{~g} \mathrm{l}^{-1}\left(20 \mathrm{~g} \mathrm{NaCl} \mathrm{l}^{-1}\right)$ (Fig. 2b). No growth was detected without sea salt. Isolate MV1087 ${ }^{\mathrm{T}} \mathrm{grew}$ 

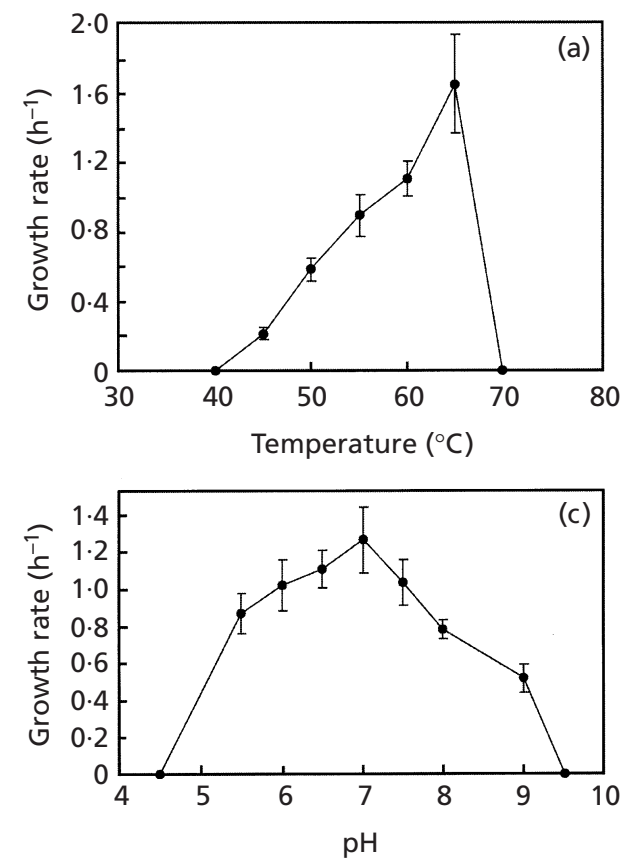

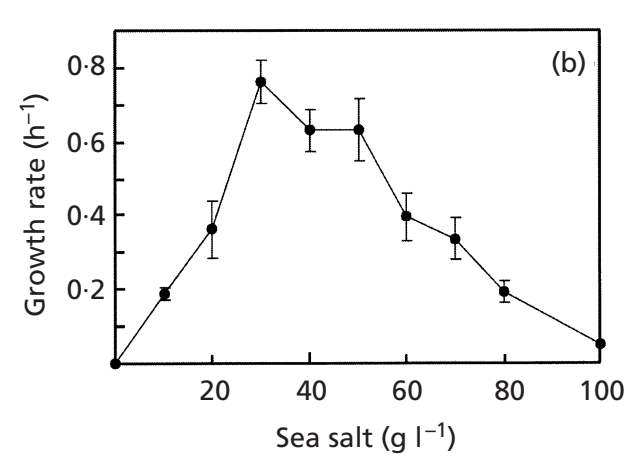

Fig. 2. Effects of (a) temperature $(\mathrm{pH} 7,30 \mathrm{~g}$ sea salt $\left.\mathrm{I}^{-1}\right)$, (b) salinity $\left(65^{\circ} \mathrm{C}, \mathrm{pH} 7\right)$ and $(\mathrm{c})$ $\mathrm{pH}\left(65^{\circ} \mathrm{C}, 30 \mathrm{~g}\right.$ sea salt $\left.\mathrm{I}^{-1}\right)$ on growth of strain MV $1087^{\top}$. from $\mathrm{pH} 5 \cdot 5$ to 9 and the optimum $\mathrm{pH}$ was around 7 (Fig. 2c). Under optimal growth conditions on YTG medium, the shortest generation time observed was $15 \mathrm{~min}$ and the maximum cell yield was $2 \times 10^{9}$ cells $\mathrm{ml}^{-1}$.

\section{Growth requirements}

Strain MV1087 $7^{\mathrm{T}}$ is heterotrophic. Growth was observed both on proteinaceous substrates and on carbohydrates. MV1087 $7^{\mathrm{T}}$ grew on brain/heart infusion or gluten at $2 \mathrm{~g} \mathrm{l}^{-1}$. Isolate $\mathrm{MV} 1087^{\mathrm{T}}$ was able to use glucose and starch with cell yields greater than $10^{9} \mathrm{ml}^{-1}$, xylan with a cell yield between $10^{8}$ and $10^{9}$ cells $\mathrm{ml}^{-1}$ and xylose with a cell yield between $5 \times 10^{7}$ and $10^{8}$ cells $\mathrm{ml}^{-1}$. It was not able to use sucrose, cellobiose, cellulose or dextran. Cell concentrations of $4 \times 10^{8}$ cells $\mathrm{ml}^{-1}$ were reached on pyruvate but none of the other organic acids or alcohols tested (methanol, ethanol, propionate and lactate) supported growth. API50CH strips showed that the strain was also able to use arabinose, ribose, galactose, fructose and sorbose, but not maltose, lactose or mannitol. Using APIZYM tests, alkaline and acid phosphatase activities were detected but not $\alpha$-mannosidase, $\alpha$-fucosidase, $\alpha$ galactosidase, $\alpha$-glucosidase, $\beta$-galactosidase or $\beta$ glucosidase activities. These last results were congruent with the inability to use lactose, maltose and cellobiose. During fermentation on YTG medium, $8 \mathrm{mM}$ glucose was consumed and $8 \mathrm{mM}$ acetate, $0 \cdot 2 \mathrm{mM}$ isovalerate and $1 \mathrm{mM}$ alanine were produced in the medium. Concentrations of proline, butyrate, propionate, phenylacetate and hydroxyphenylacetate also increased. The concentration of lactate remained unchanged during growth. The $0.2 \mathrm{mM}$ arginine pres- ent in the medium after inoculation was consumed rapidly and no arginine was then detected.

\section{Effect of electron acceptors}

Sulfur, thiosulfate, nitrate and ferric ions did not enhance growth. No growth was observed in the presence of nitrite or sulfite. Production of $\mathrm{H}_{2} \mathrm{~S}$ was detected when isolate MV1087 ${ }^{\mathrm{T}}$ was cultivated with sulfur, but not with thiosulfate or in the control without thiosulfate or sulfur. This production of $\mathrm{H}_{2} \mathrm{~S}$ was significant compared with production in uninoculated medium containing sulfur and incubated under the same conditions.

\section{DNA base composition}

The $\mathrm{G}+\mathrm{C}$ content of the DNA of isolate MV1087 was $27 \pm 1 \mathrm{~mol} \%$.

\section{$16 S$ rDNA sequence analysis}

A total of $1443 \mathrm{bp}$ of the $16 \mathrm{~S}$ rDNA sequence was determined. Comparison using BLAST with 16S rDNA sequences available in GenBank and EMBL revealed that strain MV1087 ${ }^{\mathrm{T}}$ was phylogenetically affiliated to the low-G + C-content Gram-positive bacteria. The nearest published relatives were Thermohalobacter berrensis, Clostridium acidurici, Clostridium purinilyticum and Eubacterium angustum, with respective sequence similarity values of $92,91,91$ and $89 \%$. These species belong to cluster XII of the genus Clostridium (nomenclature of Collins et al., 1994). The highest percentage similarity, $98.5 \%$, was obtained to the $16 \mathrm{~S}$ rDNA sequence of an undescribed strain, 


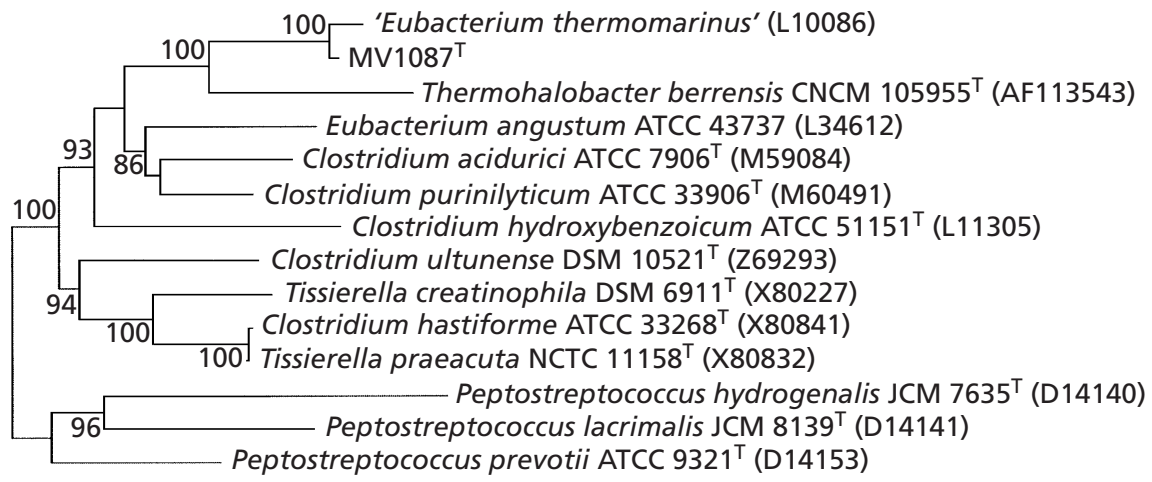

Fig. 3. Phylogenetic position of strain MV $1087^{\top}$ within cluster XII of the Clostridium subphylum of Gram-positive bacteria. A total of 1302 sites were used for the phylogenetic analysis. Alignment was performed with representatives of cluster XII, with representatives of cluster XIII as an outgroup. The topology shown is an unrooted tree obtained by a neighbourjoining algorithm (Jukes \& Cantor corrections) established using PHYLO_WIN and performed manually using SEAVIEW. Significant bootstrap values (calculated from 500 trees) are indicated as percentages at the branching points. Bar, 5.9 nt substitutions per $100 \mathrm{nt}$.

'Eubacterium thermomarinus' (accession no. L10086). This strain was isolated from the gut contents of a polychaete worm, Paralvinella sp., collected on a hydrothermal vent from the Juan de Fuca Ridge in the north-east Pacific (J. A. Baross, personal communication). An alignment was generated using $16 \mathrm{~S}$ rDNA sequences of anaerobic species of clusters XII and XIII of the genus Clostridium (sensu Collins et al., 1994) (Fig. 3). The position of MV1087 ${ }^{\mathrm{T}}$ within cluster XII of the genus Clostridium, close to Thermohalobacter berrensis, Clostridium acidurici, Clostridium purinilyticum and Eubacterium angustum, was supported by the three algorithms used: neighbour-joining, maximum-parsimony and maximum-likelihood.

\section{DISCUSSION}

Isolate $\mathrm{MV} 1087^{\mathrm{T}}$ is an anaerobic, heterotrophic thermophile of the domain Bacteria. The growth rate and DNA base composition showed the distinctiveness of isolate MV1087 ${ }^{\mathrm{T}}$ among the thermophilic, anaerobic bacteria. The usual doubling times of anaerobic, thermophilic bacteria are around 50-120 min (Wiegel, 1992); strain MV1087 ${ }^{\mathrm{T}}$ has a short doubling time of $15 \mathrm{~min}$. The $\mathrm{G}+\mathrm{C}$ content of the DNA, $27 \mathrm{~mol} \%$, is one of the lowest for a thermophilic, anaerobic bacterium. The previously observed values range from 25.6 (Caloramator indicus) to $56 \mathrm{~mol} \%$ (Clostridium thermoautotrophicum) (Wiegel, 1992; Chrisostomos et al., 1996).

The 16S rDNA sequence similarity analysis and $16 \mathrm{~S}$ rDNA phylogenetic analyses placed $\mathrm{MV} 1087^{\mathrm{T}}$ close to Thermohalobacter berrensis, Clostridium acidurici, Clostridium purinilyticum and Eubacterium angustum, within cluster XII of the Clostridium subphylum in the Gram-positive bacteria lineage (nomenclature of Collins et al., 1994). The DNA G +C contents were also similar between MV1087 ${ }^{\mathrm{T}}$ (27 mol\%), Clostridium acidurici $(28 \mathrm{~mol} \%)$ and Clostridium purinilyticum (29 mol\%) (Dürre et al., 1981; Cato et al., 1986). As with MV1087 ${ }^{\mathrm{T}}$, Thermohalobacter berrensis is an anaerobic, thermophilic, non-sporulating, rodshaped bacterium and ferments sugars (Cayol et al., 2000). However, the $16 \mathrm{~S}$ rDNA similarity values with the $16 \mathrm{~S}$ rDNA sequences of these four species were less than $93 \%$ and some phenotypic characteristics of strain $\mathrm{MV} 1087^{\mathrm{T}}$ are completely distinct. Isolate MV1087 $7^{\mathrm{T}}$ is adapted to the salinity of the ocean, with optimum growth at $2 \% \mathrm{NaCl}$. Thermohalobacter berrensis, isolated from a solar saltern, is a moderate halophile, growing in the presence of $2-15 \% \mathrm{NaCl}$ with an optimum of $5 \% \mathrm{NaCl}$ (Cayol et al., 2000). Moreover, the DNA $\mathrm{G}+\mathrm{C}$ content of Thermohalobacter berrensis, $33 \mathrm{~mol} \%$, is $6 \mathrm{~mol} \%$ higher than that of isolate MV1087 ${ }^{\mathrm{T}}$. Strain MV1087 ${ }^{\mathrm{T}}$ and Thermohalobacter berrensis do not use the same carbohydrates. In contrast to Thermohalobacter berrensis, strain MV1087 ${ }^{\mathrm{T}}$ is able to use arabinose, ribose, xylose, galactose and sorbose, but not cellobiose, maltose, sucrose, glycerol or mannitol. Isolate MV1087 ${ }^{\mathrm{T}}$ is also distinct from Clostridium acidurici, Clostridium purinilyticum and Eubacterium angustum. It is thermophilic, with an optimum growth temperature of $65^{\circ} \mathrm{C}$, while the other three bacterial species grow optimally at 36- $37{ }^{\circ} \mathrm{C}$ (Beuscher \& Andreesen, 1984). Furthermore, in contrast to isolate $\mathrm{MV} 1087^{\mathrm{T}}$, which is unable to grow without $\mathrm{NaCl}$, these species are not known to require sea salt or $\mathrm{NaCl}$ for growth. Some morphological characteristics also distinguish the marine isolate MV1087 ${ }^{\mathrm{T}}$ from the three terrestrial species. It stained Gram-negative in all phases of growth, while Clostridium purinilyticum stained Gram-positive and Clostridium acidurici stained Gram-variable. Eubacterium angustum is non-motile. MV $1087^{\mathrm{T}}$ is 
also metabolically more diverse than Eubacterium angustum, Clostridium acidurici and Clostridium purinilyticum. These three species, although they belong to two different genera, are all specialists. They are neither proteolytic nor saccharolytic and grow on purines such as uric acid and adenine but not on sugars or amino acids (except for glycine). In complete contrast, MV $1087^{\mathrm{T}}$ is saccharolytic, is able to grow on carbohydrates such as glucose and starch and is proteolytic.

The present work is the first description of an anaerobic strain of the Clostridium subphylum isolated from deep-sea hydrothermal vents. Isolate MV1087 $7^{\mathrm{T}}$ is distinct from its phylogenetically affiliated species and also has very novel characteristics among the anaerobic thermophilic bacteria. We propose that it should be assigned to a new species of a new genus of the low-G + C-content Gram-positive lineage, Caloranaerobacter azorensis gen. nov., sp. nov.

\section{Description of Caloranaerobacter Wery, Cambon-Bonavita and Barbier gen. nov.}

Caloranaerobacter (Ca.lor.an.ae.ro.bac'ter. L. n. calor heat; Gr. pref. an not; Gr. n. aer air; N.L. bacter masc. equivalent of Gr. neut. n. bakterion rod or staff; N.L. masc. n. Caloranaerobacter a thermophilic, anaerobic rod).

Rod-shaped bacterium that stains Gram-negative. Thermophilic, adapted to the $\mathrm{pH}$ and salinity of ocean waters. Anaerobic, chemo-organotrophic, able to ferment carbohydrates and proteinaceous substrates. Sulfur is not necessary for growth. The $\mathrm{G}+\mathrm{C}$ content is $27 \mathrm{~mol} \%$. $16 \mathrm{~S}$ rDNA sequence comparisons locate Caloranaerobacter in the lineage of the low- $\mathrm{G}+\mathrm{C}$ content Gram-positive bacteria, within cluster XII of the Clostridium subphylum. The type species is Caloranaerobacter azorensis.

\section{Description of Caloranaerobacter azorensis Wery, Cambon-Bonavita and Barbier sp. nov.}

Caloranaerobacter azorensis (a.zo.ren'sis. N.L. masc. adj. azorensis of the Azores).

Cells are rod-shaped, motile and stain Gram-negative. Under optimal conditions, cells appear as short rods $(0.5-2 \mu \mathrm{m}$ long by $0.3-0.5 \mu \mathrm{m}$ wide), singly, in pairs or in short chains (fewer than five cells). Growth occurs between 45 and $65^{\circ} \mathrm{C}$ (optimum $65^{\circ} \mathrm{C}$ ), pH 5.5 and 9 (optimum 7) and 10 and $100 \mathrm{~g}$ sea salts $1^{-1}$ (optimum $30 \mathrm{~g}$ sea salts $1^{-1}$ ). The optimal doubling time and maximum cell yield are respectively $15 \mathrm{~min}$ and $2 \times 10^{9}$ cells $\mathrm{ml}^{-1}$. Anaerobic. Chemo-organotrophic. Able to ferment gluten, brain/heart infusion, glucose, starch, xylan and pyruvate. The $\mathrm{G}+\mathrm{C}$ content is $27 \pm 1 \mathrm{~mol} \%$. $16 \mathrm{~S}$ rDNA sequence similarity of $92 \%$ to Thermohalobacter berrensis and $91 \%$ to Clostridium acidurici and Clostridium purinilyticum. The GenBank/EMBL accession number for the $16 \mathrm{~S}$ rDNA sequence is AJ272422.

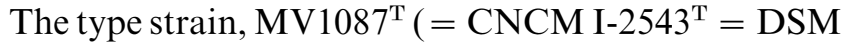
$13643^{\mathrm{T}}$ ), was isolated from chimney rocks collected on the Lucky Strike hydrothermal site on the MidAtlantic Ridge ( $32^{\circ} 16^{\prime} \mathrm{W}, 37^{\circ} 17^{\prime} \mathrm{N}$; depth $\left.1650 \mathrm{~m}\right)$.

\section{ACKNOWLEDGEMENTS}

We thank the chief scientists of the French oceanographic cruise MARVEL (1997), Daniel Desbruyères and AnneMarie Alayse (IFREMER, Centre de Brest, France), the captain and crew of N.O. Atalante and the D.S.V. Nautile pilots and support crew. We gratefully acknowledge Gerard Sinquin (Université de Bretagne Occidentale, UFR Sciences, Brest, France) for transmission electron microscopy assistance, Gérard Raguénès (IFREMER, Centre de Brest, France) for determination of the DNA base composition and John A. Baross (UW, School of Oceanography, Seattle, USA) for scientific exchanges. This research has been undertaken in the framework of the AMORES project. We acknowledge support from the European Commission's Marine Science and Technology Program (MAST III) under contract MAST3-CT95-0040. This work was also supported by the French Research Ministry and Région Bretagne.

\section{REFERENCES}

Alfredsson, G. A., Kristjansson, J. K., Hjörleifsdottir, S. \& Stetter, K. O. (1988). Rhodothermus marinus, gen. nov., sp. nov., a thermophilic, halophilic bacterium from submarine hot springs in Iceland. J Gen Microbiol 134, 299-306.

Altschul, S. F., Gish, W., Miller, W., Myers, E. W. \& Lipman, D. J. (1990). Basic local alignment search tool. J Mol Biol 215, 403-410.

Antoine, E., Cilia, V., Meunier, J. R., Guezennec, J., Lesongeur, F. \& Barbier, G. (1997). Thermosipho melanesiensis sp. nov., a new thermophilic anaerobic bacterium belonging to the order Thermotogales, isolated from deep-sea hydrothermal vents in the southwestern Pacific Ocean. Int J Syst Bacteriol 47, $1118-1123$.

Balch, W. E., Fox, G. E., Magrum, L. J., Woese, C. R. \& Wolfe, R. S. (1979). Methanogens: re-evaluation of a unique biological group. Microbiol Rev 43, 260-296.

Barbier, G., Godfroy, A., Meunier, J.-R., Quérellou, J., Cambon, M.-A., Lesongeur, F., Grimont, P. A. D. \& Raguénès, G. (1999). Pyrococcus glycovorans sp. nov., a hyperthermophilic archaeon isolated from the East Pacific Rise. Int J Syst Bacteriol 49, 1829-1837.

Beuscher, H. U. \& Andreesen, J. R. (1984). Eubacterium angustum sp. nov., a Gram-positive anaerobic, non-sporeforming, obligate purine fermenting organism. Arch Microbiol 140, $2-8$.

Bredholt, S., Sonne-Hansen, J., Nielsen, P., Mathrani, I. M. \& Ahring, B. K. (1999). Caldicellulosiruptor kristjanssonii sp. nov., a cellulolytic, extremely thermophilic, anaerobic bacterium. Int $J$ Syst Bacteriol 49, 991-996.

Cato, E. P., George, W. L. \& Finegold, S. M. (1986). Genus Clostridium Prazmowski 1880, 23 ${ }^{\mathrm{AL}}$. In Bergey's Manual of Systematic Bacteriology, vol. 2, pp. 1141-1200. Edited by P. H. A. Sneath, N. S. Mair, M. E. Sharpe \& J. G. Holt. Baltimore: Williams \& Wilkins.

Cayol, J.-L., Ducerf, S., Patel, B. K. C., Garcia, J.-L., Thomas, P. \& Ollivier, B. (2000). Thermohalobacter berrensis gen. nov., sp. nov., a thermophilic, strictly halophilic bacterium from a solar saltern. Int J Syst Evol Microbiol 50, 559-564. 
Chrisostomos, S., Patel, B. K. C., Dwivedi, P. P. \& Denman, S. E. (1996). Caloramator indicus sp. nov., a new thermophilic anaerobic bacterium isolated from the deep-seated nonvolcanically heated waters of an Indian artesian aquifer. Int $J$ Syst Bacteriol 46, 497-501.

Collins, M. D., Lawson, P. A., Willems, A., Cordoba, J. J., Fernandez-Garayzabal, J., Garcia, P., Cai, J., Hippe, H. \& Farrow, J. A. E. (1994). The phylogeny of the genus Clostridium: proposal of five new genera and eleven new species combinations. Int $J$ Syst Bacteriol 44, 812-826.

Dürre, P., Andersch, W. \& Andreesen, J. R. (1981). Isolation and characterization of an adenine-utilizing, anaerobic sporeformer, Clostridium purinolyticum sp. nov. Int J Syst Bacteriol 31, 184-194.

Farrow, J. A. E., Lawson, P. A., Hippe, H., Gauglitz, U. \& Collins, M. D. (1995). Phylogenetic evidence that the gram-negative nonsporulating bacterium Tissierella (Bacteroides) praeacuta is a member of the Clostridium subphylum of the gram-positive bacteria and description of Tissierella creatinini sp. nov. Int $J$ Syst Bacteriol 45, 436-440.

Felsenstein, J. (1981). Evolutionary trees from DNA sequences: a maximum likelihood approach. J Mol Evol 17, 368-376.

Felsenstein, J. (1985). Confidence limits on phylogenies: an approach using the bootstrap. Evolution 30, 783-791.

Galtier, N., Gouy, M. \& Gautier, C. (1996). SEAVIEW and PHYLO_WIN: two graphic tools for sequence alignment and molecular phylogeny. Comput Appl Biosci 12, 543-548.

Godfroy, A., Lesongeur, F., Raguénès, G., Quérellou, J., Antoine, E., Meunier, J.-R., Guezennec, J. \& Barbier, G. (1997). Thermococcus hydrothermalis sp. nov., a new hyperthermophilic archaeon isolated from a deep-sea hydrothermal vent. Int J Syst Bacteriol 47, 622-626.

Huber, R., Wilharm, T. \& Huber, D. \& 7 other authors (1992). Aquifex pyrophilus gen. nov., sp. nov., represents a novel group of marine hyperthermophilic hydrogen-oxidizing bacteria. Syst Appl Microbiol 15, 340-351.

Kristjansson, J. K. (editor) (1992). Thermophilic Bacteria. Boca Raton, FL: CRC Press.

Lake, J. A. (1987). A rate-independent technique for analysis of nucleic acid sequences: evolutionary parsimony. Mol Biol Evol 4, 167-191.

Manaia, C. M. \& Da Costa, M. S. (1991). Characterization of halotolerant Thermus isolates from shallow marine hot springs on S. Miguel, Azores. J Gen Microbiol 137, 2643-2648.

Marteinsson, V. T., Birrien, J.-L., Kristjansson, J. K. \& Prieur, D. (1995). First isolation of thermophilic aerobic non-sporulating heterotrophic bacteria from deep-sea hydrothermal vents. FEMS Microbiol Ecol 18, 163-174.

Marteinsson, V. T., Birrien, J.-L., Jeanthon, C. \& Prieur, D. (1996). Numerical taxonomic study of thermophilic Bacillus isolated from three geographical separated deep-sea hydrothermal vents. FEMS Microbiol Ecol 21, 255-266.

Marteinsson, V. T., Birrien, J.-L. \& Prieur, D. (1997). In situ enrichment and isolation of thermophilic microorganisms from deep-sea hydrothermal environments. Can J Microbiol 43, 694-697.
Raguénès, G., Pignet, P., Gauthier, G., Peres, A., Christen, R., Rougeaux, H., Barbier, G. \& Guezennec, J. (1996). Description of a new polymer-secreting bacterium from a deep-sea hydrothermal vent, Alteromonas macleodii subsp. fijiensis, and preliminary characterization of the polymer. Appl Environ Microbiol 62, 67-73.

Raguénès, G., Christen, R., Guézennec, J., Pignet, P. \& Barbier, G. (1997). Vibrio diabolicus sp. nov., a new polysaccharidesecreting organism isolated from a deep-sea hydrothermal vent polychaete annelid, Alvinella pompejana. Int J Syst Bacteriol 47, 989-995.

Ravot, G., Magot, M., Fardeau, M.-L., Patel, B. K. C., Thomas, P., Garcia, J.-L. \& Ollivier, B. (1999). Fusibacter paucivorans gen. nov., sp. nov., an anaerobic, thiosulfate-reducing bacterium from an oil-producing well. Int J Syst Bacteriol 49, 1141-1147.

Saitou, N. \& Nei, M. (1987). The neighbor-joining method: a new method for reconstructing phylogenetic trees. Mol Biol Evol 4, 406-425.

Slobodkin, A., Reysenbach, A.-L., Strutz, N., Dreier, M. \& Wiegel, Y. (1997a). Thermoterrabacterium ferrireducens gen. nov., sp. nov., a thermophilic anaerobic dissimilatory Fe(III)-reducing bacterium from a continental hot spring. Int J Syst Bacteriol 47, 541-547.

Slobodkin, A., Reysenbach, A.-L., Mayer, F. \& Wiegel, J. (1997b). Isolation and characterization of the homoacetogenic thermophilic bacterium Moorella glycerini sp. nov. Int J Syst Bacteriol 47, 969-974.

Slobodkin, A. I., Tourova, T. P., Kuznetsov, B. B., Kostrikina, N. A., Chernyh, N. A. \& Bonch-Osmolovskaya, E. A. (1999). Thermoanaerobacter siderophilus sp. nov., a novel dissimilatory $\mathrm{Fe}(\mathrm{III})$-reducing, anaerobic, thermophilic bacterium. Int J Syst Bacteriol 49, 1471-1478.

Takai, K. \& Horikoshi, K. (2000). Thermosipho japonicus sp. nov., an extremely thermophilic bacterium isolated from a deep-sea hydrothermal vent in Japan. Extremophiles 4, 9-17.

Takai, K., Inoue, A. \& Horikoshi, K. (1999). Thermaerobacter marianensis gen. nov., sp. nov., an aerobic extremely thermophilic marine bacterium from the $11000 \mathrm{~m}$ deep Mariana Trench. Int J Syst Bacteriol 49, 619-628.

Thompson, J. D., Higgins, D. G. \& Gibson, T. J. (1994). CLUSTAL $\mathrm{W}$ : improving the sensitivity of progressive multiple sequence alignment through sequence weighting, position-specific gap penalties and weight matrix choice. Nucleic Acids Res 22, 4673-4680.

Wery, N., Lesongeur, F., Pignet, P., Derennes, V., CambonBonavita, M.-A., Godfroy, A. \& Barbier, G. (2001). Marinitoga camini gen. nov., sp. nov., a rod-shaped bacterium belonging to the order Thermotogales, isolated from a deep-sea hydrothermal vent. Int J Syst Evol Microbiol 51, 495-504.

Wiegel, J. (1992). The obligately anaerobic thermophilic bacteria. In Thermophilic Bacteria, pp. 105-184. Edited by J. K. Kristjansson. Boca Raton, FL: CRC Press.

Willems, A. \& Collins, M. D. (1995). Evidence for the placement of the gram-negative Catonella morbi (Moore and Moore) and Johnsonella ignava (Moore and Moore) within the Clostridium subphylum of the gram-positive bacteria on the basis of $16 \mathrm{~S}$ rDNA sequences. Int $J$ Syst Bacteriol 45, 855-857. 